\title{
NATURAL AND EXPERIMENTAL INFECTION OF PLANORBIDS FROM THE ISLAND OF SANTA CATARINA (BRAZIL).
}

\author{
Karen Schmidt ESPÍNDOLA, Maria Marques MACHADO \& Paulo Roberto Petersen HOFMANN
}

\begin{abstract}
SUMMARY
Studies on eight localities on the Island of Santa Catarina revealed the presence of three species of the molluscan family Planorbidae: Biomphalaria tenagophila, Drepanotrema cimex and Biomphalaria oligoza, the first one being naturally infected by Cercaria ocellifera, a furcocercaria with morphological characteristics of Cercaria caratinguensis, and by an unknown furcocercaria. Drepanotrema cimex was infected by a furcocercaria with characteristics of $C$. caratinguensis and by $C$. macrogranulosa. No natural infection was found in $B$. oligoza. B. tenagophila showed no susceptibility to the experimental infection by the BH-MG strain of Schistosoma mansoni from Belo Horizonte and maintained at laboratory in $B$. glabrata snails.
\end{abstract}

KEY WORDS: Planorbid; Biomphalaria sp.; Drepanotrema sp.; Trematode; Cercariae; Furcocercariae; Infection; Schistosoma mansoni; Schistosomiasis.

\section{INTRODUCTION}

Many snails act as intermediate hosts of parasites whose adult forms develop in wild and domestic animals as well as in men. The planorbids, pulmonated freshwater snails belonging to the molluscan family Planorbidae, include the genus Biomphalaria Preston, 1910, which is vector of Schistosoma mansoni Sambon, 1907, the worm causing Schistosomiasis in Brazil $^{22}$. This genus comprises ten species described in this country ${ }^{\bar{\gamma}}$, three of them $(B$. glabrata, B. tenagophila and B. straminea) being effective vectors of the parasite . $^{8}$

In Brazil, such snails can be considered still more important since South-American schistosomiasis caused by $S$. mansoni prevails $^{13}$ and tends to expand. The Health Ministery estimated 5.5 million infected people within 17 studied Brazilian States in $1985^{\circ}$. Due to its relevance to public health, several authors have been trying to update information on planorbid population, such as their geographical distribution and susceptibility. According to
CUNHA $^{t}$ these are the first steps towards an epidemiological study of schistosomiasis in any region. Susceptibility studies provide data, which help to predict the potential of an area to become endemic ${ }^{3}$.

The schistosomiasis control is difficult to be made due to the epidemiological characteristics of the disease ${ }^{20}$. Its expansion, for instance, is due mainly to internal migratory movements ${ }^{18}$, responsible for new foci.

The first focus of active transmission in the State of Santa Catarina was described recently, in 1980, in the district of São Francisco do Sul ${ }^{1}$. In 1991 another one was detected in Jaraguá do Sul (FUNASA, not published data).

Planorbids are often suitable to become intermediate hosts to other trematodes besides $S$. mansoni. Many vertebrates are parasitized by digenetics whose larvae develop inside these snails ${ }^{12}$, disturbing their development and reducing their fecundity, besides inhibiting or suppressing superinfection with $S$. mansoni $i^{5}$.

Centro de Ciências Biológicas - Universidade Federal de Santa Catarina, Florianópolis, SC, Brasil. 476 - CEP 88.049 Florianópolis, SC, Brasil. 
ESPINDOLA, K.S.; MACHADO, M.M. \& HOFMANN, P.R.P. - Natural and experimental infection of planorbids from the Island of Santa Catarina (Brazil). Rev. Inst. Med. trop. S. Paulo, 34(4):289-294, 1992.

Taking these facts into account, this paper tries to supply the first data on natural and experimental infection of planorbids of the Island of Santa Catarina.

\section{MATERIAL AND METHODS}

The Island of Santa Catarina locates between $27^{\circ} 10^{\prime}$ and $27^{\circ} 50^{\prime}$ latitude South and $42^{\circ} 25^{\prime}$ and $48^{\circ} 35^{\prime}$ longitude West. The snails were collected, during 1989, at the following sites on the Island: Vargem Grande, Vargem Pequena, Ratones and Canasvieiras (Northern sites); Córrego Grande (at the Island center); and Rio Tavares, Campeche and Ribeirão da Itha (Southern sites). The collected species were taken to the laboratory and submitted to a light focus for two hours in a $50 \mathrm{ml}$ Becker cup containing $10 \mathrm{ml}$ declorated water. They were afterwards observed under stereomicroscope to detect natural infection. The snails presenting negative results were submitted to new examinations each 15 days during 75 days. Some specimens were dissected for species identification, confirmed by Dr. W. L. Paraense (Oswaldo Cruz Institute, Rio de Janeiro) and Dr. L.A. Magalhães (Biology Institute, State University of Campinas, São Paulo).

The obtained cercariae were observed at the optic microscope and photographed, being afterwards fixed in vapour formol. Species identification was confirmed by Dr. P. de T. Artigas (Parasitology Department, State University of Campinas, São Paulo) and Dr.J.F. Vaz (Biology Department, São Paulo University).

For laboratory infection by $S$. mansoni the BH-MG strain from Belo Horizonte was used.
This strain is maintained in laboratory through successive passages from albine mice to $B$. glabrata snail. Snails of $\mathrm{Fl}$ generation (approximately $8 \mathrm{~mm}$ in diameter) were exposed to ten miracidia each. The miracidia were taken from infected mice liver according to the techniques described by OLIVER-GONZALES $e t a l^{16}$ and GRIFFITHS \& BEESLEY ${ }^{6}$. B. tenagophila from São Francisco do Sul (Santa Catarina State) was used as control. The snails examination followed the techniques described by SOUZA et $a l .{ }^{21}$.

\section{RESULTS}

Just half of the eight investigated sites revealed the presence of planorbid specimens, as shown in Table 1. Between the snails collected in Córrego Grande, 30 B. tenagophila Orbigny, 1835 , presented infection by furcocercariae with characteristics of Cercaria caratinguensis Ruiz, 1953 (Fig. 1); 5 were infected with C. ocellifera Lutz, 1917 (Fig. 3) and 4 with an unknown furcocercaria (Fig. 2). Among the Drepanotrema cimex Moricand, 1839, 4 were infected with a $C$. caratinguensis-like furcocercariae; 3 with C. macrogranulosa Ruiz, 1952 (Fig. 4 ) and one with both $C$. macrogranulosa and $C$. caratinguensis-like furcocercariae.

Data referring to experimental infection of B. tenagophila by $S$. mansoni BH-MG strain are summarized in Table 2.

\section{DISCUSSION}

At the sites Vargem Grande, Vargem Pequena, Ratones and Campeche no genus of

Table 1.

Planorbids collected in four localities of the Island of Santa Catarina (Brazil), 1989.

\begin{tabular}{|c|c|c|c|}
\hline \multirow{2}{*}{ Locality and date } & \multicolumn{3}{|c|}{ Planorbid } \\
\hline & B. tenagophila & B. oligoza & Drepanotrema sp. \\
\hline \multicolumn{4}{|l|}{ Córrego Grande } \\
\hline$(10 / 1989)$ & 1303 & 0 & $25^{*}$ \\
\hline \multicolumn{4}{|l|}{ Rio Tavares } \\
\hline$(09 / 1989)$ & 0 & 8 & 0 \\
\hline \multicolumn{4}{|l|}{ Ribeirào da Ilha } \\
\hline$(09 / 1989)$ & 0 & 14 & $19 *$ \\
\hline \multicolumn{4}{|l|}{ Canasvieiras } \\
\hline$(04 / 1989)$ & 0 & 0 & 53 \\
\hline
\end{tabular}

*All planorbids $D$. cimex 


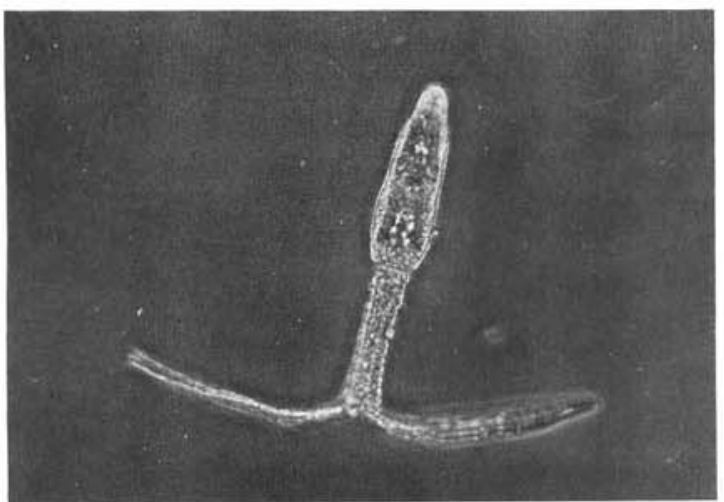

Fig. 1 - Photograph of a furcocercaria with morphologic characteristics of Cercaria caratinguensis. 240 times enhanced.

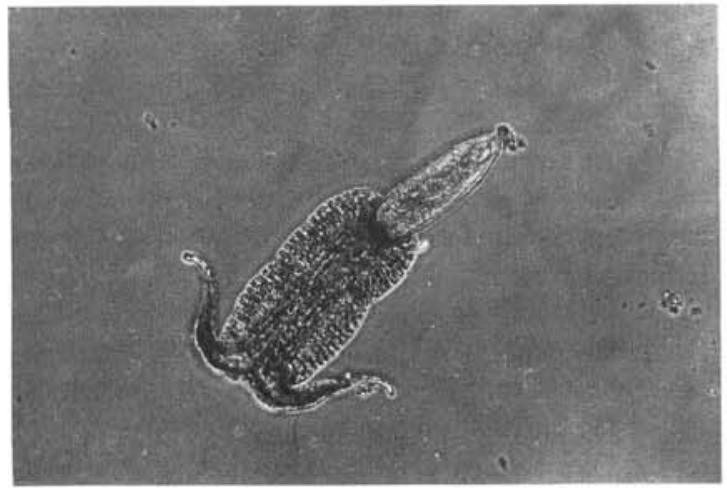

Fig. 2 - Photograph of an unknown furcocercaria. 140 times enhanced. the Planorbidae family was found. From all places where planorbids could be found, Córrego Grande presents the greatest number of snails, represented by Drepanotrema cimex and Biomphalaria tenagophila (table 1). Since the last one is intermediate host to $S$. mansoni, this locality acquires great meaning relating to sanitary conditions.

The obtained results show that while $B$. tenagophila from São Francisco do Sul had an infection index of $56.56 \%$, B. tenagophila from Córrego Grande did not show to be susceptible to BH-MG of $S$. mansoni strain. The infection was not successful in any examined snail.

In spite of these results, it is not prudent to exclude the possibility that these snails may act as intermediate hosts to other $S$. mansoni strains. It is well known that natural trematode transmission may depend critically on the degree of compatibility of local snails and trematode strains ${ }^{10}$.

For a long time B. tenagophila was considered an ineffective host for $S$. mansoni, being called Planorbis immunis by Lutz, due to experimental infection failure ${ }^{2}$. Different natural or experimental infection rates are indeed due to different degrees of physiological adaptation between parasite and host, being not only the result of high or low susceptibility to a certain snail strain ${ }^{17}$.

The area of schistosomiasis transmission through $B$. tenagophila has been expanding lately. Parasite strains which become more adapted to infect these snails may spread the disease along regions where it still does not exist $^{14}$.

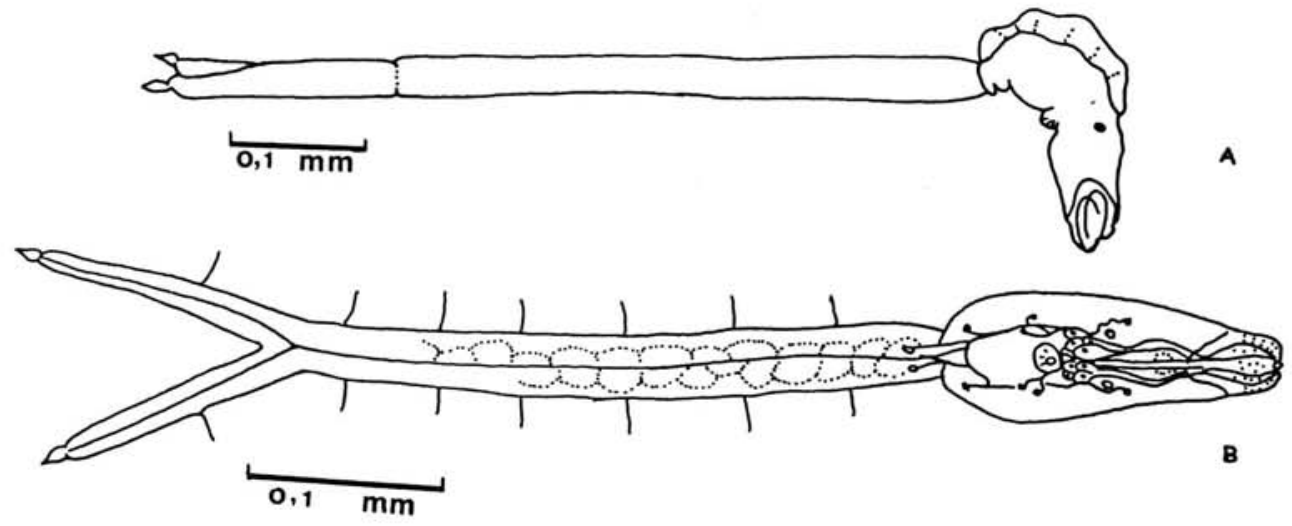

Fig. 3 - Cercaria ocellifera. A. side-view; B. ventral-view. Extracted from NARUTO, $1984^{15}$. 
ESPINDOLA, K.S.; MACHADO, M.M. \& HOFMANN, P.R.P. - Natural and experimental infection of planorbids from the Island of Santa Catarina (Brazil). Rev. Inst. Med. trop. S. Paulo, 34(4):289-294, 1992.

Table 2.

Results of the experimental infection of Biomphalaria tenagophila from Córrego Grande, Santa Catarina Island (Brazil), compared to that of São Francisco do Sul, using the BH-MG strain of Schistosoma mansoni.

\begin{tabular}{lcc}
\hline Snails & $\begin{array}{c}\text { Experimental group } \\
\text { (from Córrego Grande) }\end{array}$ & $\begin{array}{c}\text { Control group (from } \\
\text { São Francisco do Sul) }\end{array}$ \\
\hline
\end{tabular}

Exposed to infection

Examined*

Eliminating cercariae

Infection rate
105

102

$-$

$-$
122

106

69

$56.56 \%$

*Three specimens from Córrego Grande and 16 from São Francisco do Sul died.

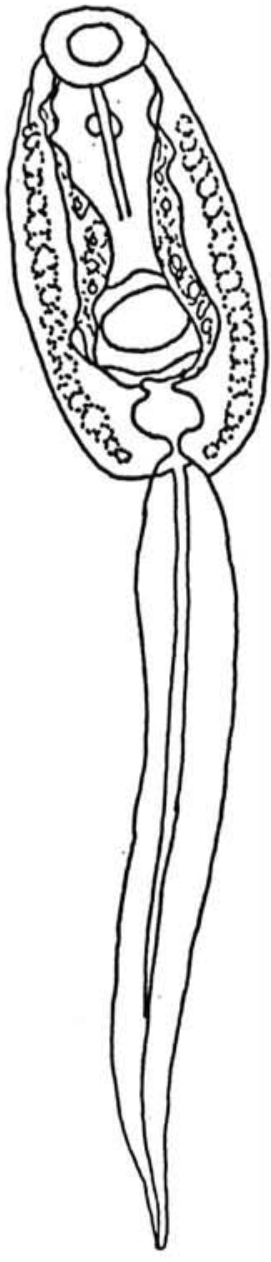

Fig. 4 - Cercaria macrogranulosa. Extracted from NARUTO, $1984^{15}$
Due to internal migration carriers of schistosomiasis are found in almost all Brazilian States, independently from the existence of a transmission focus, thus causing the development of new ones, stable or occasional ${ }^{19}$.

On what concerns natural infection our tests showed positive results just for the planorbids found at Córrego Grande, which were infected by four different trematode species. The most represented, C. caratinguensis-like furcocercariae (Fig. 1), infected $2.3 \%$ of the $B$. tenagophila snails and $16 \%$ of the Drepanotrema cimex, the later seeming to be more susceptible to this type of infection. Although the importance of investigation trematodes which have as intermediate hosts some vector snails of $S$. mansoni is evident, there are not enough anatomical data or more extensive information available. Researches studying digenetic larvae found in planorbids will certainly come across a greater diversity than the one already described. These trematodes are able to reduce or to suppress superinfection by $S$. mansoni, or also to disturb snail development ${ }^{5}$. MACHADO et al. ${ }^{12}$ verified that B. tenagophila previously infected by acculeated distomocercariae were protected from $S$. mansoni superinfection in $87 \%$ of the cases.

Investigating several specimens of $B$. tenagophila from Louveira (São Paulo State), MACHADO et al. ${ }^{11}$ found that the natural infection was monospecific in $96.56 \%$ of the snails. Contemporary parasitism was verified only in $3.35 \%$ of the cases. This corresponds to our results: just one specimen $(2.2 \%$ of the natural infected snails), Drepanotrema cimex, showed infection by C. macrogranulosa (Fig. 4) 
ESPINDOLA, K.S.; MACHADO, M.M. \& HOFMANN, P.R.P. - Natural and experimental infection of planorbids from the Island of Santa Catarina (Brazil). Rev. Inst. Med. trop. S. Paulo, 34(4):289-294, 1992.

and by a furcocercariae resembling C. caratinguensis.

The finding of a larval form such as a furcocercariae (Fig. 2), which according to Dr. P. de T. Artigas (personal communication) has not yet been described in the literature, illustrates the need for further trematode studies. We plan to describe this unknown larvae at next.

\section{RESUMO}

\section{Infecção natural e experimental de Planorbídeos da Ilha de Santa Catarina (Brasil).}

Pesquisas em oito localidades da Ilha de Santa Catarina revelaram a presença de três espécies da família Planorbidae: Biomphalaria tenagophila, Drepanotrema cimex e $B$. oligoza, estando a primeira naturalmente infectada por Cercaria ocellifera, furcocercária com características morfológicas de $C$. caratinguensis $\mathrm{e}$ uma furcocercária desconhecida. $O$ segundo molusco citado, estava infectado com $C$. macro granulosa e com furcocercária com características de C. caratinguensis, não sendo constatada infecçào natural em $B$. oligoza. No processo de infecção experimental com cepa BH-MG de Schistosoma mansoni, cepa originária de Belo Horizonte e mantida em laboratório em molusco B. glabrata, B. tenagophila não se mostrou suscetível.

\section{REFERENCES}

1. BERNARDINI, O.J. \& MACHADO, M.M. - Isolamento de Schistosoma mansoni do primeiro foco de transmissão ativa em São Francisco do Sul. Arq. Med. catarin., 10: 212, 1981.

2. CHIEFFI, P.P. - Suscctibilidade à infecção por Schistosoma mansoni, de cepas de Biomphalaria tenagophila originária dos Estados de São Paulo e Paraná. Rev. Inst. Med. trop. S. Paulo, 17: 92-96, 1975.

3. CORREA, M.C. dos R.; COELHO, P.M.Z. \& FREITAS, J.R. - Suscetibilidade de linhagens de Biomphalaria tenagophila e Biomphalaria glabrata a duas cepas de Schistosoma mansoni (LE- Belo Horizonte; MG e SJSào José dos Campos, SP). Rev. Inst. Med. trop. S. Paulo, 21: 72-76, 1979.

4. CUNHA, A.S. - Esquistossomose mansoni. São Paulo, EDUSP, 1970. p.41.
5. FRANDSEN, F. - Control of schistosomiasis by use of biological control of snail hosts with special reference to competition. Mem. Inst. Oswaldo Cruz, 82 (suppl.4): 129-133, 1987.

6. GRIFHITHS, R.B. \& BEESLEY, W.N. - A technique for the collection of large numbers of Schistosoma mansoni ova. Trans. roy. Soc. trop. Med. Hyg., 49: 301, 1955.

7. HOFMANN, P.R.P. - Aspectos da biologia e do polimorfismo enzimático em três espécies do gênero Biomphalaria. São Paulo, 1987. (Tese de Doutoramento - Instituto de Biociências da Universidade de São Paulo).

8. HOFMANN, P.R.P.; KAWANO, T. \& SIMÖES, L.C.G. - Aspectos da biologia e genética de populaçōes de três espécies do gênero Biomphalaria. Ciênc. e Cult., 37: $1286-1288,1985$.

9. JURBERG, P.; VASCONCELLOS, M.C. \& MENDES, N.M. - Plantas empregadas como moluscicidas: uma visão crítica. Mem. Inst. Oswaldo Cruz, 84 (suppl. 1): $76-83,1989$

10. LOKER, E.S. \& BAYNE, C. - Immunity to trematode larvae in the snail Biomphalaria. Symp. Zool. Soc. Lond., 56: 199-220, 1986.

11. MACHADO, S.M.P.; CORDEIRO, N. da S.; ARTIGAS, P. de T. \& MAGALHÃES, L.A. - Algumas consideraçōes sobre cercárias naturalmente encontradas em Biomphalaria tenagophila (Orbigny, 1935), capturadas em Louveira, SP. Mem. Inst. Butantan, 49: $79-86,1987$.

12. MACHADO, S.M.P.; MAGALHĀES, L.A.; ARTIGAS, P. de T.; CORDEIRO, N. da S. \& CARVALHO, J.F. de -- Verificação do antagonismo entre larvas de outros Digenea em Biomphalaria tenagophila, molusco planorbídeo de criadouro natural situado na região de Campinas, SP, Brasil. Rev. Saúde públ. (S. Paulo), 22: $484-488,1988$.

13. MALEK, E.A. - Snail hosts of schistosomiasis and other snail transmitted diseases in tropical America. A manual. Washington, Pan American Health Organization; World Health Organization, 1985. (Scientific Publication, $N^{\circ} 478$ ).

14. MELO, A.L. de \& PEREIRA, L.H. -- On the finding of Biomphalaria tenagophila naturally infected with Schistosoma mansoni in the State of Minas Gerais, Brazil. Rev. Inst. Med. trop. S. Paulo, 27: 99-101, 1985.

15. NARUTO, T. - Guia para identificação de cercárias. (Trabalho do Lab. de Malacol. da Superintend. e Controle de Endemias - SUCEN). São Paulo, 1984. p. 61.

16. OLIVER-GONZALES, J.O.; BAUMAN, P.M. \& BENENSON, A.S. - Immunological aspects of infections with Schistosoma mansoni. Amer. J. trop. Med. Hyg., 4: 443-452, 1955. 
ESPINDOLA, K.S.; MACHADO, M.M. \& HOFMANN, P.R.P. - Natural and experimental infection of planorbids from the Island of Santa Catarina (Brazil). Rev. Inst. Med. trop. S. Paulo, 34(4):289-294, 1992.

17. PARAENSE, W.L. \& CORRÊA, L.R. - Susceptibility of Australorbis tenagophilus to infection with Schistosoma mansoni. Rev. Inst. Med. trop. S. Paulo, 17: 92-96, 1963.

18. PARAENSE, W.L. \& CORRÊA, L.R. - Probable extension of schistosomiasis mansoni to Southernmost Brazil. Mem. Inst. Oswaldo Cruz, 82: 577, 1987.

19. REY, L. - Parasitologia. $2^{2}$ ed. Rio de Janeiro, Guanabara Koogan, 1991.

20. SILVEIRA, A.C. - Controle da esquistossomose no Brasil. Mem. Inst. Oswaldo Cruz, 84 (suppl. I): 91-102, 1989.
21. SOUZA, C.P. de; ARAÚJO, N.; CARVALHO, O. dos S. \& FREITAS, J.R. de -. Potencialidade de Biomphalaria tenagophila do Lago da Pampulha, Belo Horizonte, MG como hospedeiro do Schistosoma mansoni. Mem. Inst. Oswaldo Cruz, 82: 67-70, 1987.

22. TELES, H.M.S. - Aspectos ecológicos de Biomphalaria Preston, 1910 (Basommatophora, Planorbidae) no Estado de São Paulo, Brasil. I. Sintopia. Ciênc. e Cult., 40: 373-379, 1988.

Recebido para publicação em 25/07/1991 Aceito para publicaçào em 22/05/1992 